\title{
Perancangan Sistem Pemantauan Gas dan Peringatan pada Ruangan melalui Jaringan Nirkabel
}

\author{
Gunawan Kunto Bhasworo $^{1^{*}}$, Faqih Rofii ${ }^{2}$, Fachrudin Hunaini ${ }^{2}$ \\ ${ }^{I}$ Mahasiswa Jurusan Teknik Elektro, Universitas Widyagama Malang \\ ${ }^{2}$ Pengajar Jurusan Teknik Elektro, Universitas Widyagama Malang \\ Kampus III, Jl. Taman Borobudur Indah No. 3 Malang, Indonesia 65142
}

\begin{abstract}
Abstrak
Udara adalah suatu campuran gas yang terdapat pada lapisan yang mengelilingi bumi. Gas CO merupakan salah satu gas yang mengandung zat yang tidak baik yang tidak dapat ditangkap oleh panca indera, gas tersebut bersifat membunuh makhluk hidup termasuk manusia. Hidrogen sulfida $\left(\mathrm{H}_{2} \mathrm{~S}\right)$ adalah gas yang tidak berwarna, beracun, mudah terbakar dan berbau seperti telur busuk. . Konsentrasi $\mathrm{H}_{2} \mathrm{~S}$ dalam jumlah yang rendah, dapat membahayakan keselamatan manusia. Dalam konsentrasi 100 PPM dapat menyebabkan kematian dalam waktu 2-5 menit. Tidak kalah berbahayanya adalah hydrocarbon gas exploison atau ledakan yang diakibatkan kebocoran LPG (metana) pada ruang tertutup. Penelitian ini bertujuan untuk merancang dan mengimplementasikan sebuah sistem pemantau gas dan peringatan pada ruangan melalui jaringan nirkabel. Dengan menggabungkan PC (Personal Computer), Arduino, Arduino Wifi shield, Router, LCD (Liquid Crystal Display), Buzzer serta sensor gas TGS 2620 dan 2602 serta 2442 yang merupakan sensor-sensor dengan sensitivitas yang tinggi terhadap gas LPG (metana) dan $\mathrm{H}_{2} \mathrm{~S}$ serta CO dengan konsumsi daya rendah. Di peroleh sistem pemantau gas dan peringatan pada ruangan melalui jaringan nirkabel yang dapat mendeteksi dan memberikan peringatan apabila ada gas-gas berbahaya $\mathrm{CO}, \mathrm{H}_{2} \mathrm{~S}$ dan LPG (metana).
\end{abstract}

Kata kunci: Gas: CO; $\mathrm{H}_{2} S$; Metana, Arduino uno; Wifi; TGS 2620; TGS 2602; TGS 244; Sistem Pemantau Gas; Peringatan pada Ruangan; Jaringan Nirkabel

\begin{abstract}
[Title: Perancangan Sistem Pemantauan Gas dan Peringatan pada Ruangan melalui Jaringan Nirkabel] Air is a gas mixture found in the layer that surrounds the earth. CO gas is one of the gases that contain substances that are not good that can not be caught by the five senses, the gas is killing living things including humans. Hydrogen sulphide $\left(\mathrm{H}_{2} \mathrm{~S}\right)$ is a gas that is colorless, toxic, and flammable and smells like rotten eggs. Low concentrations of $\mathrm{H}_{2} \mathrm{~S}$ can harm human safety. In a concentration of 100 PPM can cause death within 2-5 minutes. No less dangerous is the hydrocarbon gas exploison or explosion caused by leakage of LPG (methane) in a closed space. This research aimed to design gas monitoring and warning system in a closed space. By combining PC (Personal Computer), Arduino, Arduino Wifi shield, Router, LCD (Liquid Crystal Display), Buzzer and gas sensors TGS 2620 and 2602 and 2442, which have high sensitivity to LPG gas (methane) and $\mathrm{H}_{2} \mathrm{~S}$ as well CO with low power consumption. Gains of gas monitoring systems and warnings in the room via wireless networks that can detect and warn if there are harmful gases $\mathrm{CO}, \mathrm{H}_{2} \mathrm{~S}$ and LPG (methane). Gas monitoring and warning systems are the objectives of this thesis.
\end{abstract}

Keywords: Gas; CO; $\mathrm{H}_{2} S$; Metana; Arduino uno; Wifi; TGS 2620; TGS 2602; TGS 2442; Gas Monitoring Systems; Room Warning; Wireless Networking

\section{Pendahuluan}

Pencemaran udara adalah suatu kondisi di mana kualitas udara menjadi rusak dan terkontaminasi oleh zatzat, baik yang tidak berbahaya maupun yang

\footnotetext{
${ }^{*}$ Penulis Korespondensi.

E-mail: gunawankb@gmail.com
}

membahayakan kesehatan tubuh manusia. Pencemaran udara biasanya terjadi di kota-kota besar dan juga daerah padat industri yang menghasilkan gas-gas yang mengandung zat di atas batas kewajaran (Yusad, 2003).

Jika udara yang dihirup tercemar dengan gas CO (Carbon Monoksida) maka udara tersebut dapat meracuni tubuh. Gas CO merupakan salah satu gas yang 


\section{Teknik, 37 (2), 2017, 82}

mengandung zat yang tidak baik yang tidak dapat ditangkap oleh panca indera. Gas tersebut bersifat membunuh makhluk hidup termasuk manusia. Gas CO akan mengganggu pengikatan oksigen pada darah karena gas ini lebih mudah terikat oleh darah dibandingkan dengan oksigen dan gas-gas lainnya. Bahaya yang muncul dari darah yang tercemar karbon monoksida dalam kadar $70 \%$ hingga $80 \%$ adalah kematian(Maryanto, Mulasari, Suryani, 2009).

Gas lain yang berbahaya adalah Hidrogen sulfida $\left(\mathrm{H}_{2} \mathrm{~S}\right)$. Ini merupakan gas yang tidak berwarna, beracun, mudah terbakar dan berbau seperti telur busuk. Gas ini terbentuk dari proses-proses industri maupun proses biologi seperti penguraian bahan-bahan organis oleh bakteri. Gas yang terdapat dalam minyak dan gas bumi, selokan, ataupun air yang tergenang ini pada konsentrasi 100 PPM dapat menyebabkan kematian dalam waktu 2-5 menit (Rahma, Prasetya, 2016).

Tidak hanya karena kandungan yang ada di dalamnya, gas juga berbahaya karena daya ledak yang bisa ditimbulkan. Banyaknya kasus kematian yang diakibatkan oleh hydrocarbon gas exploison atau ledakan yang diakibatkan kebocoran LPG (metana, butana) pada ruang tertutup (Sartika K., 2012).

Berbagai penelitian telah dilakukan terkait antisipasi bahaya gas. Penelitian itu diantaranya pendeteksi kadar gas CO (Anwari, 2011), yang memungkinkan pengiriman informasi mengenai kadar gas karbon monoksida kepada pengguna SMS. Sistem ini memiliki kekurangan dari segi efektivitas, dimana informasi hanya diterima oleh pengguna itu saja. Penelitian lain dilakukan Mulyono, Misbah, Ariwinarno (2015), di mana pada penelitian tersebut kadar gas $\mathrm{H}_{2} \mathrm{~S}$ yang terdeteksi di informasikan ke Personal Computer (PC) melalui serial kabel. Kekurangan dari sistem ini adalah gas yang dideteksi hanya untuk gas buang industry $\left(\mathrm{NH}_{3}\right.$ dan $\left.\mathrm{H}_{2} \mathrm{~S}\right)$. Selain itu kelemahan dari sistem ini adalah pada sisi efektivitas, di mana komunikasi dengan Personal Computer (PC) hanya menggunakan serial kabel. Penelitian terkait pendeteksi kadar gas LPG (Metana) juga dilakukan Bony (2011) yang menggunakan sensor gas TGS 2620. Penggunaan sensor ini adalah karena sensitivitas yang tinggi terhadap gas LPG (propana, metana dan butana), selain konsumsi daya rendah dan tahan lama.

Hingga saat ini belum ada alat yang dapat mendeteksi dua jenis gas sekaligus, misalnya LPG dan metana serta $\mathrm{H}_{2} \mathrm{~S}$. Ini menjadi peluang untuk mengembangkan alat dengan fungsi tersebut yang sekaligus menggunakan teknologi terbaru, termasuk teknologi nirkabel dalam sistem monitoring (Muchsin, Rofii, Jaenuri, 2014).

Pertimbangan-pertimbangan tersebut mendasari penelitian akan sistem dapat dimanfaatkan untuk pemantauan gas dan peringatan pada ruangan melalui jaringan nirkabel. Sistem tersebut terdiri dari Personal
Computer (PC), Arduino, Arduino Wifi shield, Router, Liquid Crystal Display (LCD), Buzzer serta sensor gas Karbon Monoksida (CO), Hydrogen Sulfide $\left(\mathrm{H}_{2} \mathrm{~S}\right)$ dan Gas LPG (Metana).

Tujuan penelitian ini adalah merancang dan mengimplementasikan sebuah sistem pemantau gas dan peringatan pada ruangan melalui jaringan nirkabel. Sistem ini bekerja dengan cara memantau kadar gas $\mathrm{CO}, \mathrm{H}_{2} \mathrm{~S}$ dan metana pada udara dalam sebuah ruangan kemudian ditampilkan dalam Liquid Crystal Display (LCD) dan PC (Personal Computer), sehingga pada saat kandungan gas berbahaya melebihi batas kadar, maka dapat memberikan peringatan dalam bentuk suara. Suara yang ditimbulkan berasal dari Buzzer yang dipasang pada ruangan yang di pantau serta device monitoring (Personal Computer).

\section{Bahan dan Metode}

a. Arduino Uno.

Arduino Uno adalah board mikrokontroler berbasis ATmega328 (datasheet). Uno berbeda dari semua papan sebelumnya karena tidak menggunakan FTDI chip driver USB to serial. Fitur Atmega16U2 (ATmega8U2 hingga versi R2) diprogram sebagai konverter USB to serial (Saputri, 2014).

b. Sensor Gas

Sensor gas terdiri dari elemen sensor, dasar sensor dan tudung sensor. Elemen sensor terdiri dari bahan sensor dan bahan pemanas untuk memanaskan elemen. Elemen sensor menggunakan bahan-bahan seperti timah (IV) Oksida $\mathrm{SnO}_{2}$, Wolfram (VI) Oksida $\mathrm{WO}_{3}$, dan lainlain tergantung pada gas yang hendak dideteksi. Gambar 1 menunjukkan susunan (struktur) dasar sensor gas.

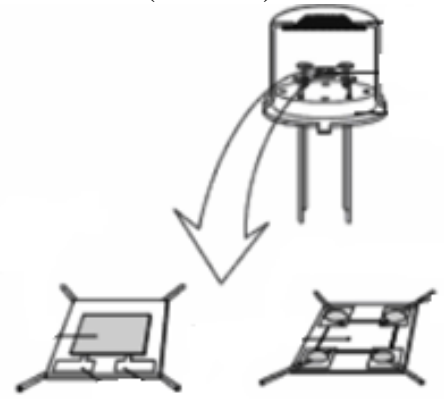

Gambar 1. Susunan dasar sensor gas

\section{c. Router}

Router adalah perangkat yang akan melewatkan paket IP (Internet Protocol) dari suatu jaringan ke jaringan yang lain, menggunakan metode addressing dan protocol tertentu untuk melewatkan paket data tersebut (Handriyanto, 2009).

\section{d. Liquid Crystal Display (LCD)}

LCD (Liquid Crystal Display) adalah salah satu jenis display elektronik yang dibuat dengan teknologi CMOS logic yang bekerja dengan tidak menghasilkan cahaya, tetapi memantulkan cahaya yang ada di 
sekelilingnya terhadap front-lit atau mentransmisikan cahaya dari back-lit (Tiffani, 2015).

e. EMS Wifi Shield

EMS Wifi Shield merupakan modul add-on/shield yang berfungsi sebagai modul Wifi untuk modul mikrokontroler Arduino. Dengan menggunakan modul ini maka modul Arduino dapat dengan mudah terhubung ke jaringan Wifi dengan hanya menggunakan antarmuka UART TTL. Modul ini bekerja pada frekuensi $2,4 \mathrm{GHz}$ dengan power output sebesar $+18 \mathrm{dBm}$. Jarak jangkauan dari modul ini sangat bergantung juga dari kekuatan sinyal dari modul Wifi yang terhubung seperti Wifi Router, Personal Computer (sebagai access point) ataupun smartphone Android OS (tethering)(Vidy, 2014).

\section{f. Software Arduino}

Software Arduino yang digunakan dalam penelitian ini adalah driver dan IDE, walaupun masih ada beberapa software lain yang sangat berguna selama pengembangan Arduino.

\section{g. Borland Delphi 10}

Borland Delphi 10 adalah paket bahasa pemrograman yang bekerja dalam sistem operasi Windows. Delphi merupakan bahasa pemrograman yang mempunyai cakupan kemampuan yang luas dan sangat canggih. Berbagai jenis aplikasi dapat anda buat dengan Delphi, termasuk aplikasi untuk mengelolah teks, grafik, angka, database dan aplikasi web (Hendrayudi, 2008). Delphi menggunakan struktur bahasa pemrograman Object Pascal yang sudah dikenal di kalangan pemrograman professional. Gabungan dari object dan bahasa pemrograman ini sering disebut sebagai bahasa pemrograman berorientasi objek atau Object Oriented Programing (OOP) (Ichwan, 2010). Selain itu Delphi juga dapat menangani data dalam berbagai format database. Format database yang dianggap asli dari Delphi adalah Paradox dan Dbase (Alam, Agus, 2003)

\section{Hasil dan Pembahasan}

\subsection{Blok Diagram Secara Umum Sistem}

Sistem pemantau, pendeteksi dan peringatan gas beracun $\mathrm{CO}, \mathrm{H}_{2} \mathrm{~S}$ dan metana/butana berbasis Arduino dapat diilustrasikan dengan Gambar 2. Sistem kerja dimulai ketika sensor gas mendeteksi adanya gas yang berbahaya di daerah sekitar sensor atau di ruangan tertentu, kemudian sinyal tersebut dikondisikan oleh rangkaian pengkondisi sinyal dan diterima oleh mikrokontroler. Rangkaian pengkondisi sinyal yang berfungsi untuk mengkonversi resistansi menjadi tegangan. Mikrokontroler mengolah data dengan mengkonversi data analog yang diterima kedalam bentuk data digital dan menampilkannya melalui LCD (Liquid Crystal Display) serta dilogging melalui PC untuk ditampilakan datanya.

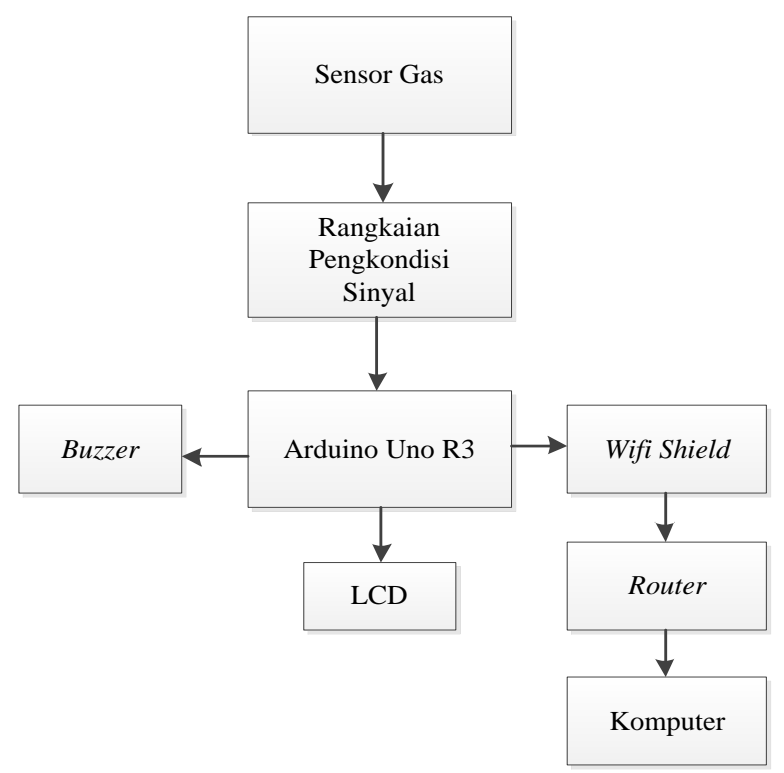

Gambar 2. Diagram blok sistem pemantau gas dan peringatan pada ruangan melalui jaringan nirkabel

\subsection{Perencanaan Perangkat Keras}

Rangkaian Mikrokontroller dengan ouput yang merupakan perencanaan perangkat keras terdiri dari Arduino Uno, LCD dan Buzzer (Gambar3).

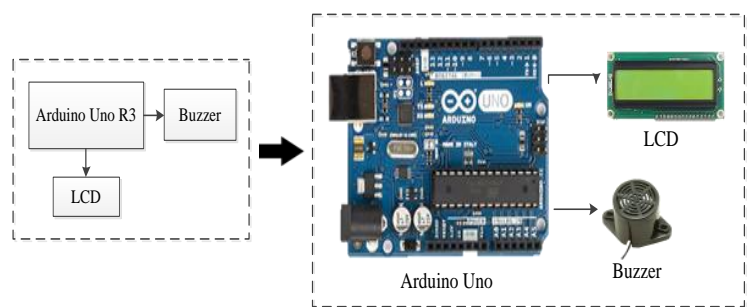

Gambar 3. Rangkaian mikrokontroler dengan output

\subsubsection{Perangkat input dan Output}

Rangkaian perangkat input (Gambar 4) terdiri dari sensor gas dan rangkaian pengkondisi sinyal. Perancangan dan pembuatan rangkaian pengkondisi sinyal terbagi menjadi dua yaitu, rangkaian pengkondisi sinyal sensor gas $\mathrm{CO}$ serta rangkaian pengkondisi sinyal sensor gas $\mathrm{H}_{2} \mathrm{~S}$ dan sensor gas metana.

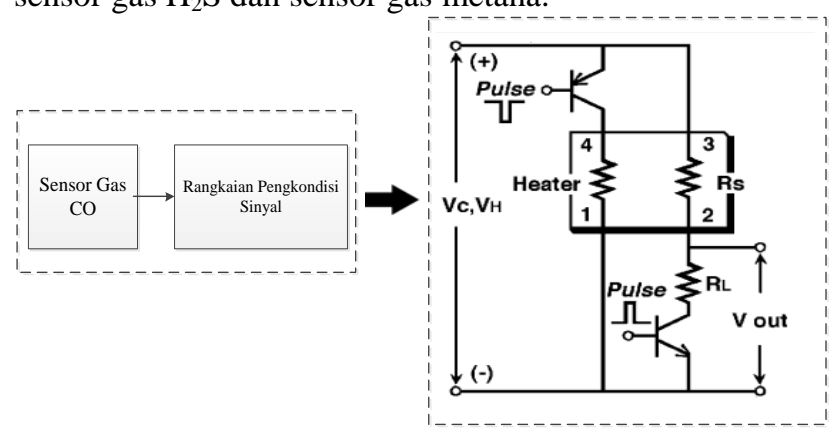

Gambar 4. Rangkaian perangkat input 
Rangkaian perangkat output (Gambar 5) terdiri dari LCD dan buzzer. Buzzer berfungsi sebagai indikator/alarm saat kandungan gas berbahaya yang terdeteksi oleh sensor melebihi kadar 50\%. Selain melalui PC (Personal Computer), nilai kadar gas dalam udara juga dapat dilihat melalui LCD (Liquid Crystal Display) sesuai dengan satuanya masing-masing.

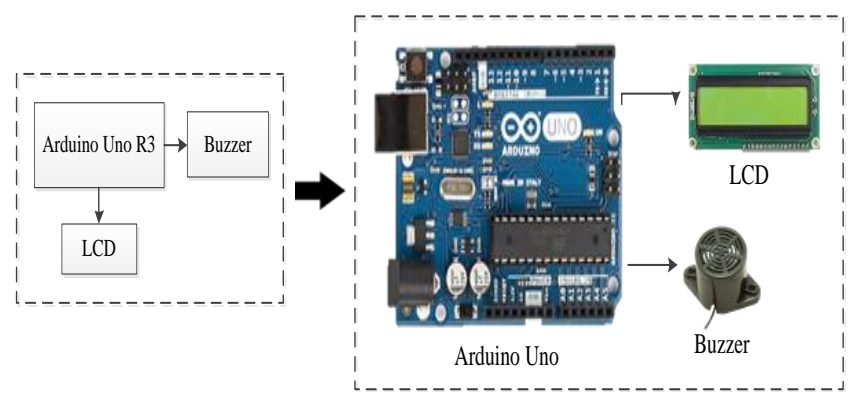

Gambar 5. Rangkaian perangkat output

\subsubsection{Komunikasi serial antara mikrokontroler dengan Wifi Shield}

Perangkat keras komunikasi serial antara mikrokontroler dengan Wifi shield ditunjukkan pada Gambar 6.

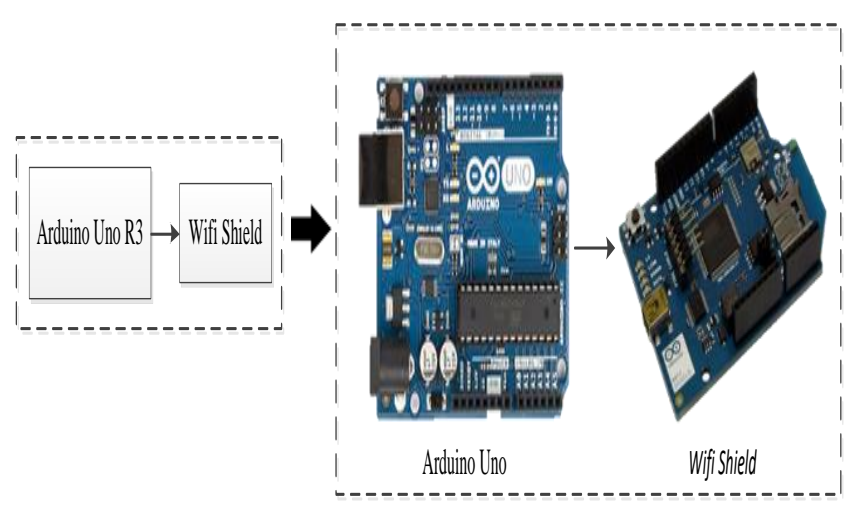

Gambar 6. Komunikasi antara mikrokontroler dengan Wifi Shield

\subsubsection{Komunikasi antara Wifi Shield dengan PC}

Wifi shield mengirim data digital ke PC (Personal Computer) melalui jaringan wireless dengan menggunakan perangkat keras Router yang menjembatani komunikasi diantara keduanya. Gambar 7 menunjukkan komunikasi antara Wifi shield dengan PC (Personal Computer).

\subsubsection{Box rangkaian}

Box adalah sebuah kotak yang memiliki bentuk tiga dimensi yang digunakan untuk meletakkan perangkat keras sistem pemantau gas, sehingga lebih simpel dan mudah dibawa-bawa. Adapun perangkat keras yang akan diletakkan ke dalam box seperti pada Gambar 8 meliputi sensor dan rangkaian pengkondisi sinyal, rangkaian mikrokontroler Arduino Uno, buzzer, LCD (Liquid Crystal Display) dan Wifi Shield.

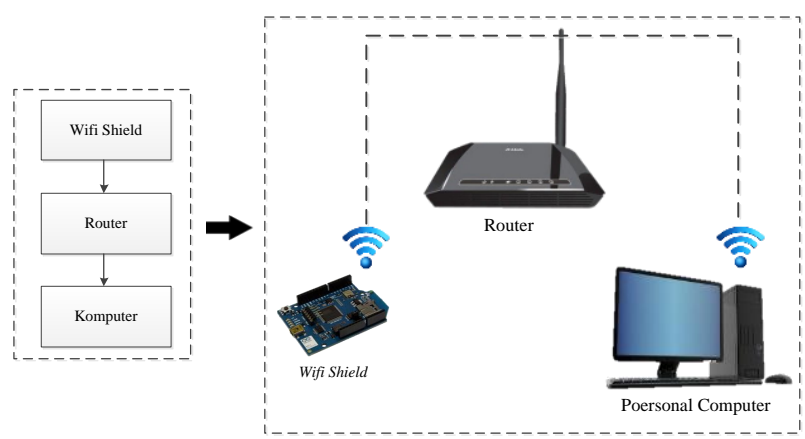

Gambar 7. Komunikasi antara Wifi Shield dengan PC

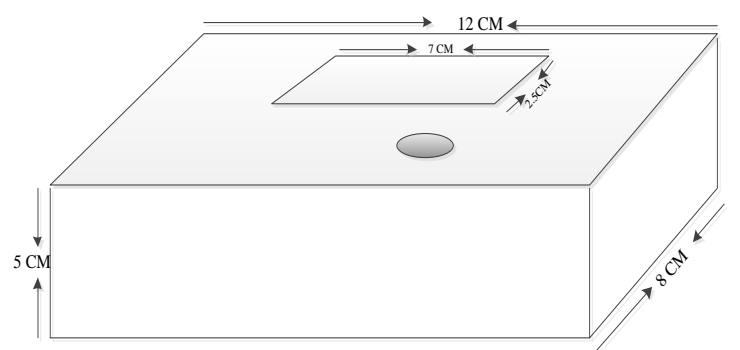

Gambar 8. Dimensi box rangkaian

\subsection{Perencanaan Perangkat Lunak}

Perancangan dan pembuatan perangkat lunak terdiri dari perancangan dan pembuatan perangkat lunak mikrokontroler Arduino dan database MySQL. Gambar 9 menunjukkan diagram alir sistem kerja pemantau dan pendeteksi gas berbahaya.

Sistem kerja pada perangkat lunak dimulai dari inisialisasi Wifi, inisialisasi ADC sensor dan inisialisasi SPI (Serial Peripheral Interface), kemudian dilanjutkan dengan proses baca sensor dan logging data sensor, selanjutnya apakah Personal Computer (PC) logging. Jika 'tidak' maka proses selesai dan jika 'ya' maka data sensor dikirim ke PC (Personal Computer), dan selanjutnya kembali lagi proses baca sensor dan begitu seterusnya.

\subsubsection{Aplikasi Logger dan Database}

Perangkat lunak aplikasi data logger sistem pemantau dan pendeteksi gas memiliki alur kerja seperti yang ditunjukkan dalam Gambar 10. Hasil perancangan aplikasi dioperasikan melalui PC (Personal Computer) dengan sistem kerja dimulai dari inisialisasi Wifi, inisialisasi database MySQL, kemudian dilanjutkan dengan pemilihan data sensor yang akan dibaca dan diproses, selanjutnya hasil pembacaan akan disimpan dan ditampilkan dalam bentuk laporan atau report.

Sistem kerja pada PC (Personal Computer) dimulai dari inisialisasi Wifi, inisialisasi database MySql, kemudian dilanjutkan dengan pemilihan data sensor yang akan di proses dan logging data sensor, selanjutnya hasil akan ditampilkan dalam bentuk laporan atau report. 
Teknik, 37 (2), 2017, 85

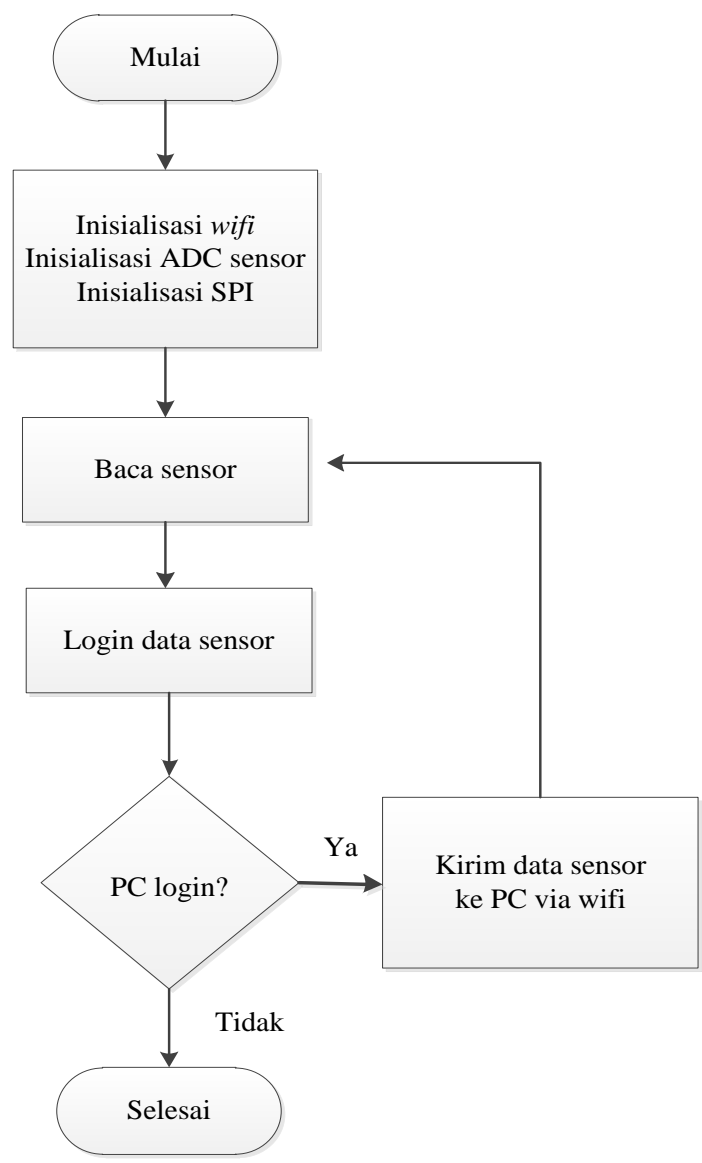

Gambar 9. Flowchart sistem kerja pemantau dan pendeteksi gas berbahaya

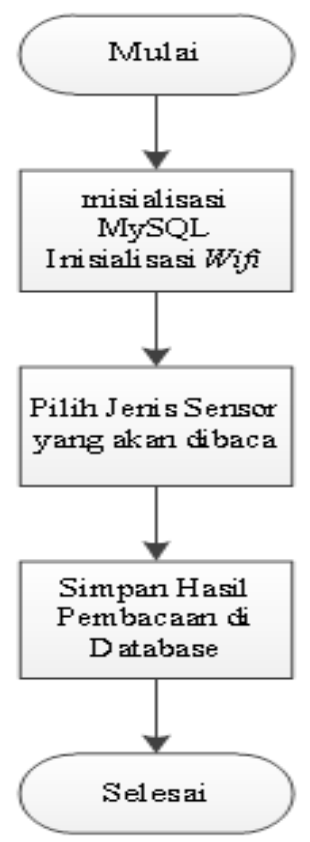

Gambar 10. Flowchart aplikasi logger dan database

\subsubsection{Arduino Uno menggunakan mikrokontroler ATMega328}

Gambar 11 menunjukkan flowchart program mikrokontroler. Sistem kerja pada Arduino dimulai dari inisialisasi Wifi, inisialisasi ADC sensor dan inisialisasi SPI (Serial Peripheral Interface), kemudian dilanjutkan dengan proses baca sensor dan loging data sensor, selanjutnya apakah Personal Computer (PC) loging? Jika 'tidak' maka proses selesai dan jika 'ya' maka data sensor dikirm ke PC (Personal Computer), dan selanjutnya kembali lagi proses baca sensor dan begitu seterusnya.

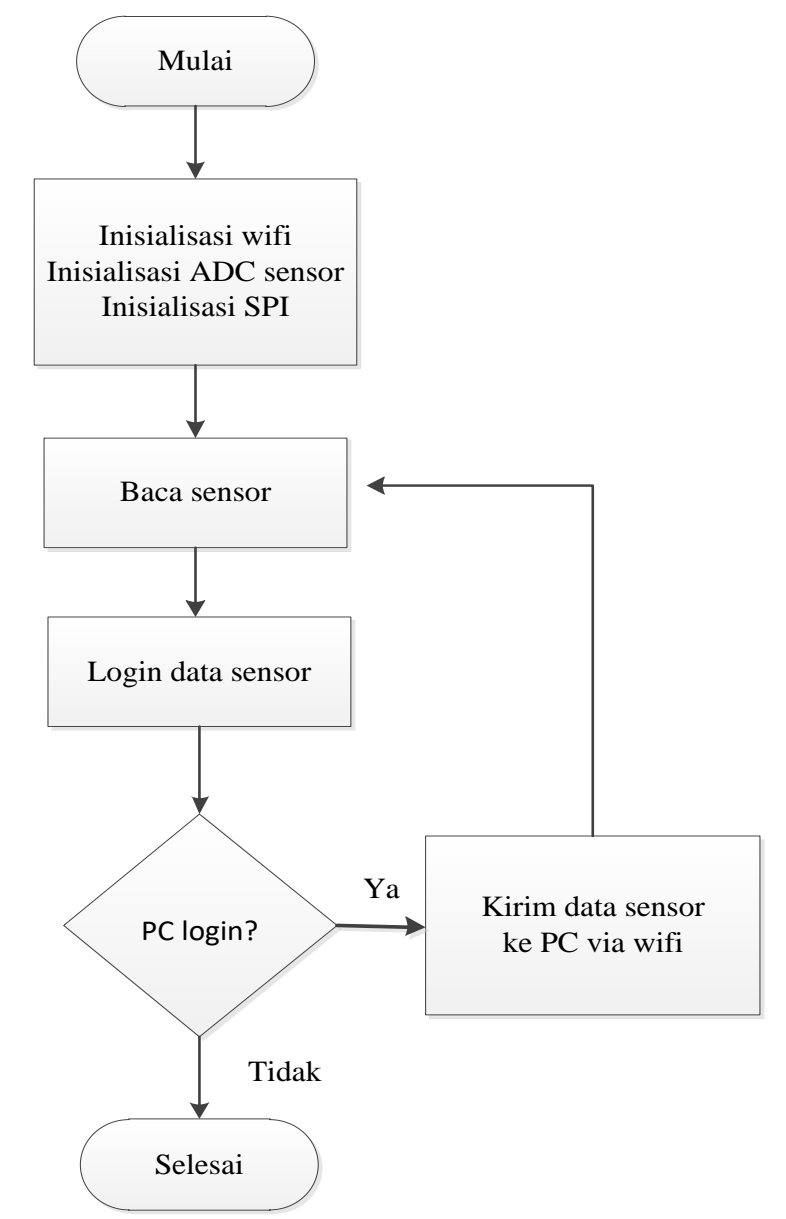

Gambar 11. Flowchart program Arduino

\subsection{Pembuatan Sistem \\ 3.4.1 Pembuatan perangkat keras}

Pada tahap pembuatan perangkat keras ini terdiri dari semua pembuatan perangkat-perangkat keras yang direalisasikan sesuai dengan rancangan. Pada proses pembuatan perangkat keras ini meliputi bagian elektronik dan bagian mekanik. Gambar 12 menunjukkan tampilan rangkaian pada kotak rangkaian. 


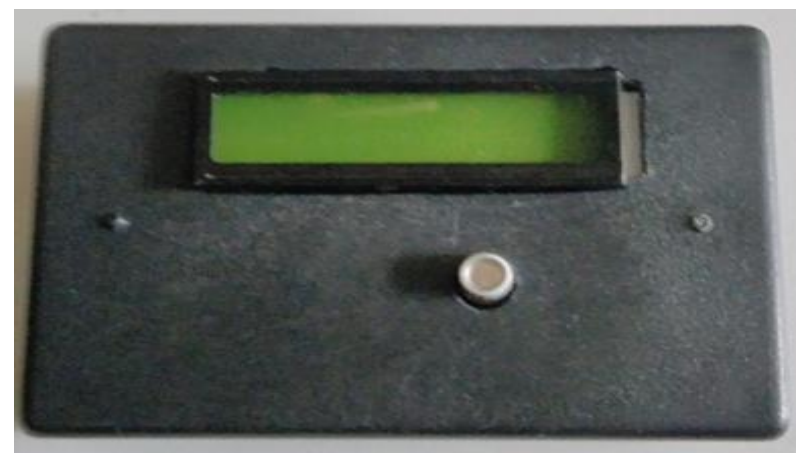

Gambar 12. Tampilan rangkaian pada kotak rangkaian

\subsubsection{Pembuatan perangkat lunak}

\subsubsection{Pembuatan program arduino uno} menggunakan mikrokontroler ATMega328

Pada Gambar 13 menunjukkan tampilan menu upload pada Software Arduino Uno, di mana dari menu tersebut dapat melakukan upload software pada Arduino Uno.

(2) TGS442| Arduino 1.8.1

\section{V $\rightarrow$ 圆 $4 \pm$}

\section{TGS442}

\section{\#include <Liquidcry stal.h
\#include $\langle$ Sof twareserial. $h>$}

Liquidcrystal 1 cd (13, $12,11,10,9,8$
Softuareserial Serial1 12,3$)$

byte i;
float Va11, CO, m2442, RS, RASIO, PPM;

void setup ()

// put your setup code here, to run once:

lod.begin $(16,2)$

led.print (" TGS $2442 \quad ")$;

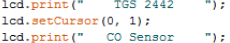

led.print (" co Sensor
Serial.begin ( 9600$)$;
analogReference (EXTERNAI)

analogReference (EXIERR,
pInMode (c1rc, OUI PUI);

pinMode (heat, OUTPUT);
pinMode (buzz, OUTPUI);

digitalWrite(circ, IoW);

Gambar 13. Tampilan menu upload pada Software Arduino Uno

\subsubsection{Pembuatan Aplikasi Logger dan Database}

Adapun bentuk perancangan aplikasi data logger sistem pemantau dan pendeteksi gas berbahaya adalah seperti dalam Gambar 14 tampilan depan aplikasi dan Gambar 15 tampilan aplikasi logger .

PERANCANGAN SISTEM PEMANTAU GAS DAN PERINGTAN PADA RUANGAN MELALUI JARINGAN NIRKABEL

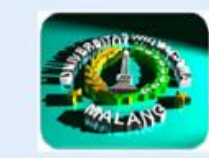

OLEH :

GUNAWAN KUNTO BHASWORO 152045920933

KONSENTRASI ELEKTRONIKA

TEKNIK ELEKTRO FAKULTAS TEKNIK

UNIVERSITAS WIDYAGAMA MALANG

Gambar 14. Tampilan depan aplikasi

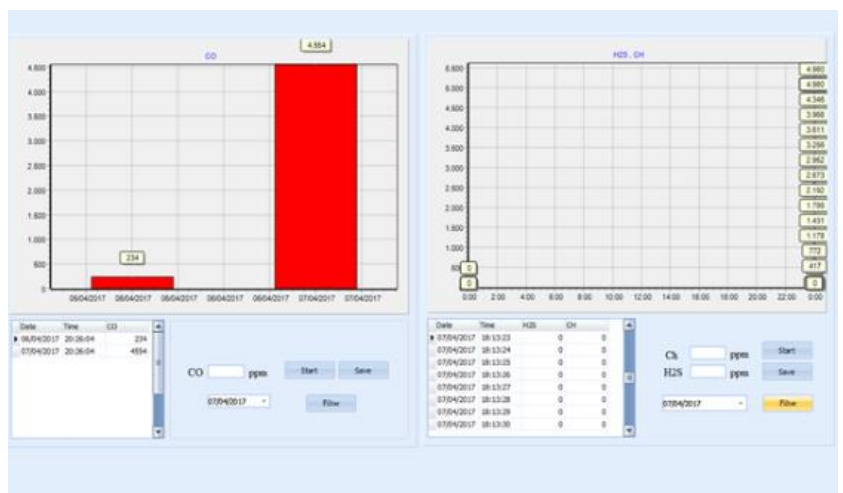

Gambar 15. Tampilan aplikasi logger

\subsection{Pengujian Perangkat Keras}

3.1.1 Pengujian Rangkaian Mikrokontroler Arduino UNO

Pengujian modul mikrokontroler Arduino UNO dilakukan dengan cara mengisi program terlebih dahulu menggunakan Arduino IDE (Integrated Development Environment), dengan meng-compile program ke mikrokontroler dapat diketahui adanya error. Program dijalankan dengan cara menghubungkan komputer dengan perangkat modul mikrokontroler Arduino Uno. Gambar 16 menunjukkan blok diagram pengujian Arduino Uno. Pengujian Arduino berhasil dilakukan, terlihat dari indikasi LED pada board Arduino Uno.

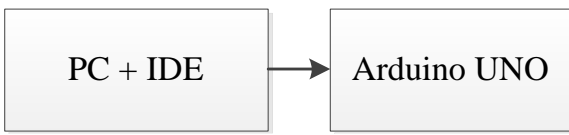

Gambar 16. Pengujian Arduino Uno

\section{a. Pengujian Sensor dan Rangkaian Pengkondisi Sinyal}

Pengujian ini meliputi pengujian sensor gas $\mathrm{CO}$, $\mathrm{H} 2 \mathrm{~S}$ dan Metana. Tujuan pengujian ini dilakukan untuk mengetahui nilai resistansi yang dihasilkan oleh sensorsensor tersebut ketika sedang mendeteksi gas. Data nilai resistansi tersebut tidak dapat dibaca langsung oleh rangkaian mikrokontroler Arduino. Dengan demikian dibutuhkan rangkaian pengkondisi sinyal yang berfungsi untuk mengkonversi resistansi menjadi tegangan. Adapun hasil pengujian sensor terhadap rangkaian pengkondisi sinyal dapat dilihat dalam Tabel 1, Tabel 2 dan Tabel 3.

Berdasarkan hasil percobaan sensor pada Tabel 1 saat mendeteksi gas $\mathrm{CO}$, maka diperoleh nilai rasio resistansi:

$$
\begin{array}{ll}
\text { Rs } & =40.9 \mathrm{~K} \Omega \\
\text { Ro } & =13.3 \mathrm{~K} \Omega
\end{array}
$$

$$
\begin{aligned}
& R s=\frac{V c \times K L}{\text { Vout }}-R L \\
& 40.9 \mathrm{~K} \Omega=\frac{5 \text { volt } x 10 \mathrm{~K} \Omega}{\text { Vout }}-10 \mathrm{~K} \Omega
\end{aligned}
$$


Teknik, 37 (2), 2017, 87

$$
\begin{aligned}
& 40.9+10 \mathrm{~K} \Omega=\frac{50 \mathrm{~V} \cdot \mathrm{K} \Omega}{\text { Vout }} \\
& \text { Vout }=\frac{50 \mathrm{~V} \cdot \mathrm{K} \Omega}{50,9 \mathrm{~K} \Omega} \\
& \text { Vout }=0,982 \text { Volt }
\end{aligned}
$$

Tabel 1. Hasil pengukuran sensor gas $\mathrm{CO}$

\begin{tabular}{cccc}
\hline $\begin{array}{c}\text { Resistansi Sendor } \\
\text { CO }(\text { Ohm })\end{array}$ & $\begin{array}{c}\text { Hasil } \\
\text { Perhitungan } \\
\text { (Volt) }\end{array}$ & $\begin{array}{c}\text { Hasil } \\
\text { Pengukuran } \\
\text { (Volt) }\end{array}$ & $\begin{array}{c}\text { Deviasi } \\
\text { (error) }\end{array}$ \\
\hline 40916.45 & 0.982 & 0.980 & 0.002 \\
40150.45 & 0.997 & 1.000 & 0.003 \\
39652.43 & 1.007 & 1.010 & 0.003 \\
38030.74 & 1.041 & 1.040 & 0.001 \\
35085.66 & 1.109 & 1.110 & 0.001 \\
33516.1 & 1.149 & 1.150 & 0.001 \\
32087.54 & 1.188 & 1.190 & 0.002 \\
30916.53 & 1.222 & 1.220 & 0.002 \\
30128.41 & 1.246 & 1.250 & 0.004 \\
28610.04 & 1.295 & 1.300 & 0.005 \\
28022.81 & 1.315 & 1.320 & 0.005 \\
\hline \multicolumn{4}{c}{ Average Deviasi (Error) } \\
\hline
\end{tabular}

Berdasarkan hasil percobaan sensor pada Tabel 2 saat mendeteksi gas $\mathrm{H}_{2} \mathrm{~S}$, maka diperoleh nilai rasio resistansi:

$$
\begin{aligned}
& \mathrm{Rs}=8.06 \mathrm{~K} \Omega \\
& \mathrm{Ro}=10 \mathrm{~K} \Omega \\
& R s=\frac{\text { Vc } x \mathrm{KL}}{\text { Vout }}-R L \\
& 8.06 \mathrm{~K} \Omega=\frac{5 \text { volt } x 1 \mathrm{~K} \Omega}{\text { Vout }}-1 \mathrm{~K} \Omega \\
& 8.06+1 \mathrm{~K} \Omega=\frac{5 \mathrm{~V} \cdot \mathrm{K} \Omega}{\text { Vout }} \\
& \text { Vout }=\frac{5 \mathrm{~V} \cdot \mathrm{K} \Omega}{9.06 \mathrm{~K} \Omega} \\
& \text { Vout }=0,552 \text { Volt }
\end{aligned}
$$

Tabel 2. Hasil pengukuran sensor gas $\mathrm{H}_{2} \mathrm{~S}$

\begin{tabular}{cccc}
\hline $\begin{array}{c}\text { Resistansi } \\
\text { Sendor H2 } \\
(\mathbf{O h m})\end{array}$ & $\begin{array}{c}\text { Hasil } \\
\text { Perhitungan } \\
\text { (Volt) }\end{array}$ & $\begin{array}{c}\text { Hasil } \\
\text { Pengukuran } \\
\text { (Volt) }\end{array}$ & $\begin{array}{c}\text { Deviasi } \\
\text { (error) }\end{array}$ \\
\hline 8057.97 & 0.552 & 0.55 & 0.002 \\
7591.07 & 0.582 & 0.58 & 0.002 \\
7319.47 & 0.601 & 0.6 & 0.001 \\
6936.51 & 0.63 & 0.63 & 0.000 \\
6256.89 & 0.689 & 0.69 & 0.001 \\
5684.49 & 0.748 & 0.75 & 0.002 \\
5518.9 & 0.767 & 0.77 & 0.003 \\
5203.47 & 0.806 & 0.81 & 0.004 \\
4882.35 & 0.85 & 0.85 & 0.000 \\
4561.74 & 0.899 & 0.9 & 0.001 \\
4165.29 & 0.968 & 0.97 & 0.002 \\
\hline \multicolumn{4}{c}{ Average Deviasi (Error) } \\
\hline
\end{tabular}

Berdasarkan hasil percobaan sensor pada Tabel 3 saat mendeteksi gas metana, maka diperoleh nilai rasio resistansi:

$$
\begin{aligned}
& \mathrm{Rs}=18 \mathrm{~K} \Omega \\
& \mathrm{Ro}=1 \mathrm{~K} \Omega \\
& R s=\frac{\text { Vc } x \mathrm{KL}}{\text { Vout }}-R L \\
& 18 \mathrm{~K} \Omega=\frac{5 \text { volt } x 1 \mathrm{~K} \Omega}{\text { Vout }}-1 \mathrm{~K} \Omega \\
& 18+1 \mathrm{~K} \Omega=\frac{5 \mathrm{~V} \cdot \mathrm{K} \Omega}{\text { Vout }} \\
& \text { Vout }=\frac{5 \mathrm{~V} \cdot \mathrm{K} \Omega}{19 \mathrm{~K} \Omega} \\
& \text { Vout }=0,254 \text { Volt }
\end{aligned}
$$

Tabel 3. Hasil pengukuran gas metana

\begin{tabular}{cccc}
\hline $\begin{array}{c}\text { Resistansi } \\
\text { Sendor } \\
\text { Metana } \\
\text { (Ohm) }\end{array}$ & $\begin{array}{c}\text { Hasil } \\
\text { Perhitungan } \\
\text { (Volt) }\end{array}$ & $\begin{array}{c}\text { Hasil } \\
\text { Pengukuran } \\
\text { (Volt) }\end{array}$ & $\begin{array}{c}\text { Deviasi } \\
\text { (error) }\end{array}$ \\
\hline 18001.04 & 0.254 & 0.25 & 0.002 \\
14479.88 & 0.323 & 0.32 & 0.002 \\
11787.72 & 0.391 & 0.39 & 0.001 \\
9989.01 & 0.455 & 0.46 & 0.005 \\
8560.23 & 0.523 & 0.52 & 0.003 \\
7183.31 & 0.611 & 0.61 & 0.001 \\
6102.27 & 0.704 & 0.7 & 0.004 \\
4681.82 & 0.880 & 0.88 & 0.000 \\
4265.29 & 0.968 & 0.97 & 0.002 \\
3826.25 & 1.036 & 1.04 & 0.004 \\
3448.4 & 1.124 & 1.12 & 0.004 \\
\hline \multicolumn{4}{c}{ Average Deviasi (Error) } \\
\hline
\end{tabular}

\section{b. Pengujian LCD (Liquid Crystal Display)}

Pengujian pada LCD (Liquid Crystal Display) dilakukan dengan cara menulis listing program pada fungsi main(). Pengujian LCD berhasil dilakukan, ditunjukkan dengan munculnya tulisan pada LCD.

\section{c. Pengujian Buzzer}

Buzzer biasa digunakan sebagai indikator bahwa proses telah selesai atau terjadi suatu kesalahan pada sebuah alat (Tiffani, 2015). Hasil pengujian Buzzer saat mendeteksi gas beracun terlihat pada Tabel 4, Tabel 5 dan Tabel 6. Hasil pengujian Buzzer saat mendeteksi gas CO terlihat pada Tabel 4, hasil pengujian Buzzer saat mendeteksi gas $\mathrm{H}_{2} \mathrm{~S}$ terlihat pada Tabel 5 dan hasil pengujian Buzzer saat mendeteksi gas Metana terlihat pada tabel 6.

Tabel 4. Hasil pengujian buzzer saat mendeteksi gas CO

\begin{tabular}{ccc}
$\begin{array}{c}\text { Batas Ambang Gas } \\
\text { CO }\end{array}$ & $\begin{array}{c}\text { Tegangan pada } \\
\text { Port 13 }\end{array}$ & Buzzer \\
\hline$<100$ PPM & 0 Volt & Mati \\
$\geq 100$ PPM & 5 Volt & Nyala \\
\hline
\end{tabular}


Teknik, 37 (2), 2017, 88

Tabel 5. Hasil pengujian buzzer saat mendeteksi gas $\mathrm{H}_{2} \mathrm{~S}$

\begin{tabular}{ccc}
\hline $\begin{array}{c}\text { Batas Ambang Gas } \\
\mathbf{H}_{2} \mathbf{S}\end{array}$ & $\begin{array}{c}\text { Tegangan pada Port } \\
\mathbf{1 3}\end{array}$ & Buzzer \\
\hline$<10 \mathrm{PPM}$ & 0 Volt & Mati \\
$\geq 10 \mathrm{PPM}$ & 5 Volt & Nyala \\
\hline
\end{tabular}

Tabel 6. Hasil pengujian buzzer saat mendeteksi gas metana

\begin{tabular}{ccc}
\hline $\begin{array}{c}\text { Batas Ambang Gas } \\
\text { Metana }\end{array}$ & $\begin{array}{c}\text { Tegangan pada Port } \\
\mathbf{1 3}\end{array}$ & Buzzer \\
\hline$<300$ PPM & 0 Volt & Mati \\
$\geq 300$ PPM & 5 Volt & Nyala \\
\hline
\end{tabular}

\section{d. Pengujian Koneksi Wifi Shield}

Pengujian ini dilakukan untuk mengetahui fungsi komunikasi Wifi shield. Hasil pengujian komunikasi Wifi shield menunjukkan Wifi telah terkoneksi.

\subsection{Pengujian Secara keseluruhan}

Pengujian secara keseluruhan (Gambar 17) dapat dilakukan dengan cara mengukur dan menghitung beberapa parameter pada setiap pengujian masing-masing gas $\left(\mathrm{CO}, \mathrm{H}_{2} \mathrm{~S}\right.$ dan metana).

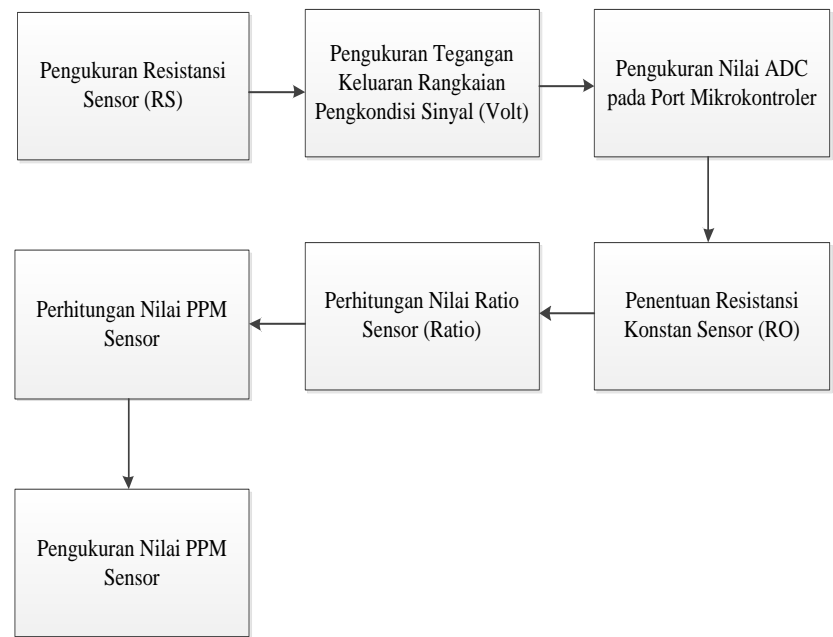

Gambar 17. Langkah langkah pengujian secara keseluruhan

Berikut hasil perangkat yang digunakan untuk melakukan pengujian sistem secara keseluruhan seperti di tunjukkan dalam Gambar 18.

Tahap awal pengujian secara keseluruhan dilakukan dengan cara menguji masing-masing modul pendeteksi sensor, sehingga nilai PPM gas yang dideteksi dapat ditampilkan dalam LCD dan aplikasi pemantau gas. Berikut hasil pengujian sistem sensor saat mendeteksi gas, seperti di tunjukkan dalam Gambar 19 dan Gambar 20.

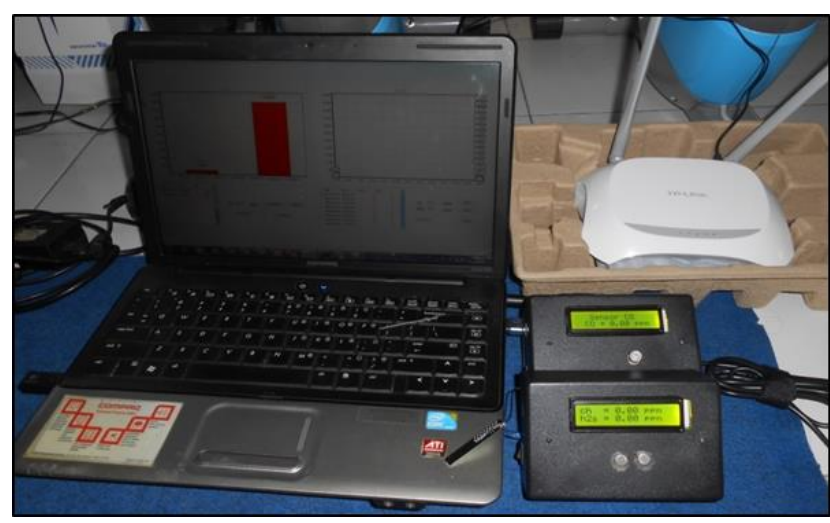

Gambar 18. hasil perancangan perangkat sistem pendeteksi gas

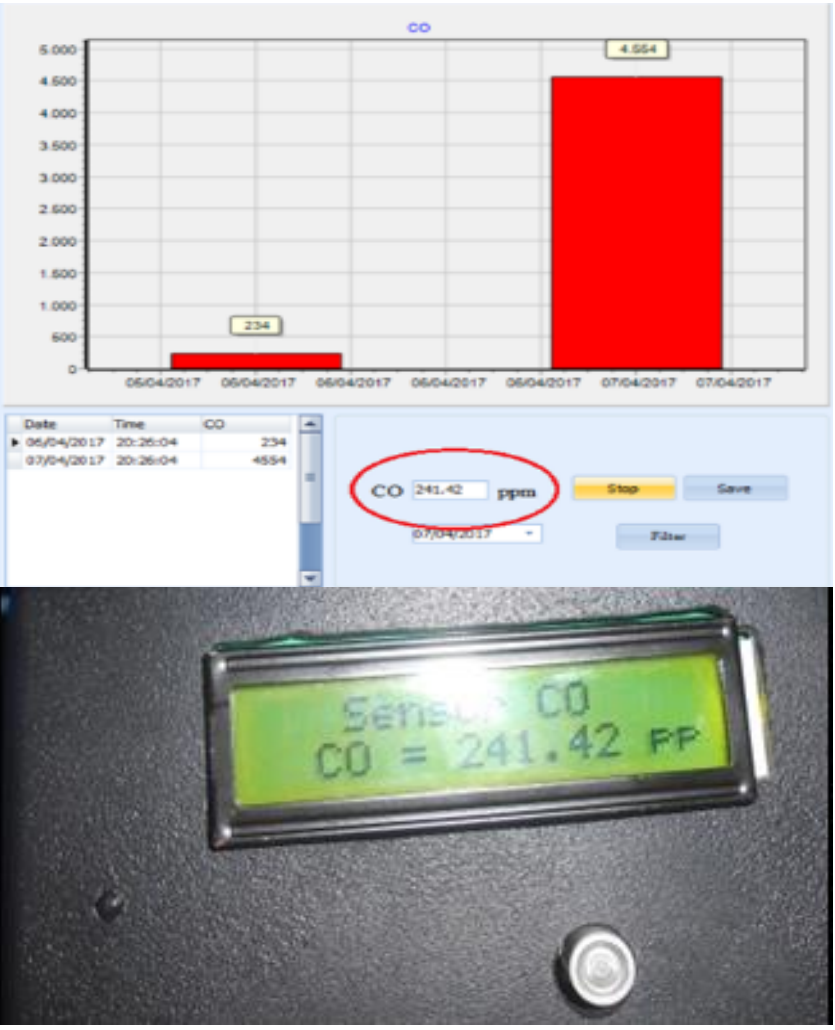

Gambar 19. Pengujian sistem saat sensor mendeteksi Gas CO

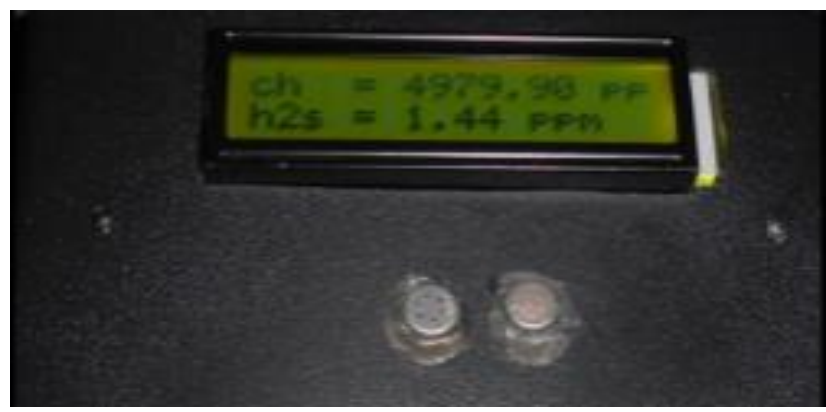

Gambar 20. Pengujian sistem saat sensor mendeteksi Gas $\mathrm{H}_{2} \mathrm{~S}$ dan Metana 
Teknik, 37 (2), 2017, 89

Dapat dilihat bahwa nilai PPM yang ditampilkan pada LCD sama dengan nilai PPM yang ditampilkan pada aplikasi pemantau gas. Hasil pengujian masing-masing sensor gas ( $\mathrm{CO}, \mathrm{H}_{2} \mathrm{~S}$ dan Metana) yang diambil dengan nilai PPM yang bervariasi:

a. Gas CO

Berdasarkan hasil percobaan sensor pada Tabel 7 saat mendeteksi gas $\mathrm{CO}$, maka diperoleh nilai rasio resistansi:

$$
\begin{aligned}
& \text { Rs } \quad=40.9 \mathrm{~K} \Omega \\
& \text { Ro }=13.3 \mathrm{~K} \Omega \\
& \text { Rasio }=40.9 / 13.3 \\
& =3.08 \\
& (\mathrm{x}-\mathrm{x} 1) /(\mathrm{x} 2-\mathrm{x} 1)=(\mathrm{y}-\mathrm{y} 1) /(\mathrm{y} 2-\mathrm{y} 1) \\
& \mathrm{x} 1=12 \mathrm{PPM} \\
& \mathrm{x} 2=1000 \mathrm{PPM} \\
& \mathrm{y} 1=4 \\
& \text { y2 }=0.8 \\
& \mathrm{CO}=(988 \mathrm{y}-3999.04) /(-3.92) \\
& \mathrm{CO}=(988(3.08)-3999.04) /(-3.92) \\
& \mathrm{CO}=(3043.04-3999.04) /(-3.92) \\
& \mathrm{CO}=244.78 \mathrm{PPM}
\end{aligned}
$$

Tabel 7. Hasil Pengujian Gas CO

\begin{tabular}{cccccc}
\hline $\begin{array}{c}\text { RS } \\
(\mathbf{O h m})\end{array}$ & $\begin{array}{c}\text { RO 100 } \\
\text { PPM } \\
(\mathbf{O h m})\end{array}$ & $\begin{array}{c}\text { Ratio } \\
(\mathbf{R S} / \mathbf{R})\end{array}$ & $\begin{array}{c}\text { PPM } \\
\text { Terhitung }\end{array}$ & $\begin{array}{c}\text { PPM } \\
\text { Terukur }\end{array}$ & $\begin{array}{c}\text { Deviasi } \\
\text { (Error) }\end{array}$ \\
\hline 40916.50 & 13300.00 & 3.08 & 244.78 & 244.67 & 0.11 \\
40916.50 & 13300.00 & 3.08 & 245.78 & 245.21 & 0.57 \\
40150.45 & 13300.00 & 3.02 & 259.29 & 259.21 & 0.08 \\
39652.43 & 13300.00 & 2.98 & 268.73 & 268.59 & 0.14 \\
38030.74 & 13300.00 & 2.86 & 299.46 & 299.35 & 0.11 \\
35085.66 & 13300.00 & 2.64 & 355.27 & 355.19 & 0.08 \\
33516.10 & 13300.00 & 2.52 & 385.02 & 384.95 & 0.07 \\
32087.54 & 13300.00 & 2.41 & 412.09 & 412.03 & 0.06 \\
30916.53 & 13300.00 & 2.32 & 434.28 & 434.19 & 0.09 \\
30128.41 & 13300.00 & 2.27 & 449.22 & 449.12 & 0.10 \\
28610.04 & 13300.00 & 2.15 & 477.99 & 477.81 & 0.18 \\
\hline \multicolumn{5}{c}{ Average Deviasi (Error) } \\
\hline
\end{tabular}

b. $\mathrm{Gas}_{2} \mathrm{~S}$

Berdasarkan hasil percobaan sensor pada Tabel 8 saat mendeteksi gas $\mathrm{H}_{2} \mathrm{~S}$, maka diperoleh nilai rasio resistansi:

Rs $\quad=8.06 \mathrm{~K} \Omega$

$$
\begin{aligned}
& \text { Ro } \quad=10 \mathrm{~K} \Omega \\
& \text { Rasio }=8.06 / 10 \\
& =0.81 \\
& \mathrm{x} 1=0.1 \mathrm{PPM} \\
& \mathrm{x} 2=2 \mathrm{PPM} \\
& \mathrm{y} 1=0.8 \\
& \mathrm{y} 2=0.25 \\
& (\mathrm{x}-0.1) /(2-0.1)=(\mathrm{y}-0.8) /(0.25-0.8) \\
& (\mathrm{x}-0.1) / 1.9=(\mathrm{y}-0.8) /(-0.55) \\
& \mathrm{x}=(1.9 \mathrm{y}-1.58) /(-0.55)
\end{aligned}
$$

$$
\begin{aligned}
& \mathrm{H} 2 \mathrm{~S}=(1.9 \mathrm{y}-1.58) /(-0.55) \\
& \mathrm{H} 2 \mathrm{~S}=(1.9(0.81)-1.58) /(-0.55) \\
& \mathrm{H} 2 \mathrm{~S}=(1.54-1.58) /(-0.55) \\
& \mathrm{H} 2 \mathrm{~S}=0.08 \mathrm{PPM}
\end{aligned}
$$

Tabel 8. Hasil Pengujian $\mathrm{Gas}_{2} \mathrm{~S}$

\begin{tabular}{cccccc}
\hline $\begin{array}{c}\text { RS } \\
(\mathbf{O h m})\end{array}$ & $\begin{array}{c}\text { RO in } \\
\text { Air } \\
(\mathbf{O h m})\end{array}$ & $\begin{array}{c}\text { Ratio } \\
(\mathbf{R S} / \mathbf{R O})\end{array}$ & $\begin{array}{c}\text { PPM } \\
\text { Terhitun } \\
\mathbf{g}\end{array}$ & $\begin{array}{c}\text { PPM } \\
\text { Teruku } \\
\mathbf{r}\end{array}$ & $\begin{array}{c}\text { Deviasi } \\
\text { (Error) } \\
\text { PPM }\end{array}$ \\
\hline 8057.97 & 10000 & 0.81 & 0.08 & 0.05 & 0.03 \\
7594.07 & 10000 & 0.76 & 0.24 & 0.19 & 0.05 \\
7319.47 & 10000 & 0.73 & 0.34 & 0.29 & 0.05 \\
6936.51 & 10000 & 0.69 & 0.47 & 0.45 & 0.02 \\
6256.89 & 10000 & 0.63 & 0.7 & 0.68 & 0.02 \\
5684.49 & 10000 & 0.57 & 0.9 & 0.85 & 0.05 \\
5518.9 & 10000 & 0.55 & 0.96 & 0.95 & 0.01 \\
5203.47 & 10000 & 0.52 & 1.07 & 1.05 & 0.02 \\
4882.35 & 10000 & 0.49 & 1.18 & 1.15 & 0.03 \\
4561.74 & 10000 & 0.46 & 1.29 & 1.27 & 0.02 \\
4165.29 & 10000 & 0.42 & 1.47 & 1.44 & 0.03 \\
\hline \multicolumn{7}{c}{ Average Deviasi (Error) } \\
\hline \multicolumn{7}{c}{}
\end{tabular}

c. Gas Metana

Berdasarkan hasil percobaan sensor pada Tabel 9 saat mendeteksi gas metana, maka diperoleh nilai rasio resistansi:

$$
\begin{array}{ll}
\text { Rs } & =18 \mathrm{~K} \Omega \\
\text { Ro } & =1 \mathrm{~K} \Omega \\
\text { Rasio } & =18 / 1 \\
& =18
\end{array}
$$$$
(\mathrm{x}-40) /(5000-40)=(\mathrm{y}-18) /(2.7-18)
$$$$
(\mathrm{x}-40) / 4960=(\mathrm{y}-18) /(-15.3)
$$$$
\mathrm{x}=(4960 \mathrm{y}-89892) /(-15.3)
$$

Metana $=(4960 \mathrm{y}-89892) /(-15.3)$

Metana $=(4960(18)-89892) /(-15.3)$

Metana $=(89280-89892) /(-15.3)$

Metana $=39.66 \mathrm{PPM}$

Tabel 9. Hasil Pengujian Gas Metana

\begin{tabular}{cccccc}
\hline $\begin{array}{r}\text { RS } \\
(\mathbf{O h m})\end{array}$ & $\begin{array}{c}\mathbf{R O} \\
\mathbf{3 0 0} \\
\mathbf{p p m} \\
(\mathbf{O h m})\end{array}$ & $\begin{array}{c}\text { Ratio } \\
(\mathbf{R S} / \mathbf{R O}\end{array}$ & $\begin{array}{c}\text { PPM } \\
\text { Terhitun } \\
\mathbf{g}\end{array}$ & $\begin{array}{c}\text { PPM } \\
\text { Terukur }\end{array}$ & $\begin{array}{c}\text { Deviasi } \\
(\text { Error }) \\
\text { PPM }\end{array}$ \\
\hline 14479.9 & 1000 & 14.48 & 1191.16 & 1180.9 & 0.26 \\
11787.7 & 1000 & 11.79 & 2053.91 & 2053.63 & 0.28 \\
9989.01 & 1000 & 9.99 & 2637 & 2636.89 & 0.11 \\
8560.23 & 1000 & 8.56 & 3100.21 & 3100.02 & 0.19 \\
7183.31 & 1000 & 7.18 & 3546.59 & 3546.46 & 0.13 \\
6102.27 & 1000 & 6.1 & 3897.04 & 3896.93 & 0.11 \\
4681.82 & 1000 & 4.68 & 4357.53 & 4357.47 & 0.06 \\
4165.29 & 1000 & 4.17 & 4524.98 & 4524.56 & 0.42 \\
3826.25 & 1000 & 3.8 & 4634.89 & 4634.69 & 0.20 \\
3448.4 & 1000 & 3.45 & 4757.38 & 4757.26 & 0.12 \\
2762.23 & 1000 & 2.76 & 4979.98 & 4979.9 & 0.08 \\
\hline \multicolumn{5}{c}{ Average Deviasi (Error) } \\
\hline
\end{tabular}


Berdasarkan tabel hasil pengujian sistem pada saat masing-masing sensor ( $\mathrm{CO}, \mathrm{H}_{2} \mathrm{~S}$ dan Metana) mendeteksi gas menunjukkan bahwa:

a. Hasil pengujian gas $\mathrm{CO}$ menunjukkan bahwa selisih atau error terbesar PPM terukur dengan PPM terhitung adalah 0,14 PPM.

b. Hasil pengujian gas $\mathrm{H}_{2} \mathrm{~S}$ menunjukkan bahwa selisih atau error terbesar PPM terukur dengan PPM terhitung adalah 0,03 PPM.

c. Hasil pengujian gas $\mathrm{CO}$ menunjukkan bahwa selisih atau error terbesar PPM terukur dengan PPM terhitung adalah 0,17 PPM.

Untuk mengetahui kecepatan response sensor saat mendeteksi gas, maka di lakukan percobaan untuk mengetahui response waktu masing-masing sensor. Hasil pengujian dapat dilihat pada Tabel 10 untuk hasil pengujian sensor Gas Metana, Tabel 11 untuk hasil pengujian sensor Gas $\mathrm{H}_{2} \mathrm{~S}$ dan Tabel 12 untuk hasil pengujian sensor Gas CO.

Tabel 10. Hasil pengujian sensor gas Metana

\begin{tabular}{cccc}
\hline $\begin{array}{c}\text { Jarak antara source } \\
\text { gas dengan alat }(\mathbf{C m})\end{array}$ & $\begin{array}{c}\text { PPM } \\
\text { Terukur }\end{array}$ & $\begin{array}{c}\text { Waktu } \\
\text { Untuk } \\
\text { Mendeteksi } \\
\text { (Detik) }\end{array}$ & $\begin{array}{c}\text { Waktu } \\
\text { Reset ke } \\
\text { 0 PPM } \\
\text { (Detik) }\end{array}$ \\
\hline 30 & 0 & - & - \\
20 & 2944 & 12 & 24.3 \\
10 & 4988 & 2.8 & 33.4 \\
\hline
\end{tabular}

Tabel 11. Hasil pengujian sensor gas $\mathrm{H}_{2} \mathrm{~S}$

\begin{tabular}{cccc}
$\begin{array}{c}\text { Jarak antara source } \\
\text { gas dengan alat }(\mathbf{C m})\end{array}$ & $\begin{array}{c}\text { PPM } \\
\text { Terukur }\end{array}$ & $\begin{array}{c}\text { Waktu } \\
\text { Untuk } \\
\text { Mendeteksi } \\
\text { (Detik) }\end{array}$ & $\begin{array}{c}\text { Waktu } \\
\text { Reset ke } \\
\text { 0 PPM } \\
\text { (Detik) }\end{array}$ \\
\hline 30 & 0 & - & - \\
20 & 0 & - & - \\
10 & 0 & - & - \\
5 & 1.44 & 2.8 & 3.1 \\
\hline
\end{tabular}

Tabel 12. Hasil pengujian sensor gas $\mathrm{CO}$

\begin{tabular}{cccc}
\hline $\begin{array}{c}\text { Jarak antara source } \\
\text { gas dengan alat }(\mathbf{C m})\end{array}$ & $\begin{array}{c}\text { PPM } \\
\text { Terukur }\end{array}$ & $\begin{array}{c}\text { Waktu } \\
\text { Untuk } \\
\text { Mendeteksi } \\
\text { (Detik) }\end{array}$ & $\begin{array}{c}\text { Waktu } \\
\text { Reset ke } \\
\text { 0 PPM } \\
\text { (Detik) }\end{array}$ \\
\hline 30 & 123.56 & 3.1 & 33 \\
20 & 244.78 & 2.3 & 56 \\
10 & 355.27 & 1.2 & 73 \\
\hline
\end{tabular}

Berdasarkan tabel hasil pengujian kecepatan sensor saat mendeteksi gas (Metana, $\mathrm{H}_{2} \mathrm{~S}$, dan $\mathrm{CO}$ ) diketahui bahwa semakin dekat jarak antara sumber gas dan alat (sensor) maka semakin cepat response alat (sensor) untuk mendeteksi dan semakin besar juga PPM terukur dan semakin besar PPM terukur maka semakin lama waktu yang di butuhkan alat (sensor) untuk kembali ke posisi pengukuran 0 PPM.

Secara keseluruhan sistem telah diuji, sehingga dapat diketahui bahwa jarak koneksi antara Wifi dengan komputer (aplikasi pemantau gas) pada saat sistem pemantau gas beroperasi atau diaktifkan dapat dilihat seperti dalam Tabel 13 Hasil pengujian koneksi Wifi dengan penghalang dan Tabel 14 Hasil pengujian koneksi Wifi tanpa penghalang.

Berdasarkan Tabel 13 dan Tabel 14 hasil pengujian koneksi Wifi menunjukkan bahwa koneksi antara Wifi dengan komputer dengan menggunakan penghalang dapat dilakukan dengan maksimal jarak 10 samapi 12 meter, sedangkan tanpa menggunakan penghalang dapat dilakukan dengan maksimal jarak 16 sampai 18 meter.

Tabel 13. Hasil pengujian koneksi Wifi dengan penghalang

\begin{tabular}{cccc}
\hline \multicolumn{4}{c}{ Pengukuran Jarak Koneksi Wifi } \\
\hline $\begin{array}{c}\text { Jarak dengan } \\
\text { penghalang (meter) }\end{array}$ & CO & CH & $\mathrm{H}_{2} \mathrm{~S}$ \\
\hline 2 & OK & OK & OK \\
4 & OK & OK & OK \\
6 & OK & OK & OK \\
8 & OK & OK & OK \\
10 & OK & OK & OK \\
12 & OK & - & - \\
14 & - & - & - \\
16 & - & - & - \\
18 & - & - & - \\
20 & - & - & - \\
\hline
\end{tabular}

Tabel 14. Hasil pengujian koneksi Wifi tanpa penghalang

\begin{tabular}{cccc}
\hline \multicolumn{4}{c}{ Pengukuran Jarak Koneksi Wifi } \\
\hline $\begin{array}{c}\text { Jarak tanpa } \\
\text { penghalang (meter) }\end{array}$ & CO & CH & $\mathrm{H}_{2} \mathrm{~S}$ \\
\hline 2 & OK & OK & OK \\
4 & OK & OK & OK \\
6 & OK & OK & OK \\
8 & OK & OK & OK \\
10 & OK & OK & OK \\
12 & OK & OK & OK \\
14 & OK & OK & OK \\
16 & OK & OK & OK \\
18 & - & OK & OK \\
20 & - & - & - \\
\hline
\end{tabular}

\section{Kesimpulan}

Berdasarkan hasil pengujian sistem pemantau gas yang dirancang dapat disimpulkan bahwa sistem pemantau gas dan peringatan pada ruangan melalui jaringan nirkabel dapat dikontrol dengan menggunakan mikrokontroler Arduino Uno. Mikrokontroler mengolah data dengan cara data analog yang diterima dikonversikan kedalam bentuk data digital dan kemudian nilai PPM ditampilkan ke dalam LCD (Liquid Crystal Display) serta disimpan ke MMC shield. Data yang 
Teknik, 37 (2), 2017, 91

disimpan ke MMC shield akan di loging melalui PC untuk ditampilakan datanya.

Aplikasi sistem pemantau gas dapat berfungsi sebagai media interface data logging, nilai kandungan gas berbahaya pada udara dapat diketahui melalui aplikasi tersebut dalam bentuk satuan PPM. Sedangkan Router berfungsi untuk menjembatani komunikasi antara Wifi shield dengan PC (Personal Computer) dengan cara mengunakan jaringan LAN melalui wireless.

Hasil pengujian sensor gas $\mathrm{CO}, \mathrm{H}_{2} \mathrm{~S}$ dan metana menunjukkan bahwa besar nilai resistansi yang dideteksi oleh sensor berbanding terbalik dengan nilai tegangan yang dihasilkan. Semakin besar nilai resistansi yang diperoleh maka semakin kecil nilai tegangannya dan sebaliknya semakin kecil nilai resistansi yang diperoleh maka semakin besar nilai tegangannya.

Berdasarkan hasil pengujian sistem pada saat masing-masing sensor $\left(\mathrm{CO}, \mathrm{H}_{2} \mathrm{~S}\right.$ dan Metana) mendeteksi gas menunjukkan bahwa: rata-rata selisih hasil pengujian nilai PPM terukur dengan nilai PPM terhitung adalah kurang dari 0,2 PPM, selisih PPM disebabkan oleh beberapa faktor, salah satunya adalah faktor nilai toleransi resistor yang digunakan pada perangkat hardware.

Hasil pengujian kecepatan sensor dalam mendeteksi gas menunjukkan bahwa adanya hubungan jarak dengan kecepatan sensor dalam mendeteksi gas dan besar nya PPM yang di tampilkan. Semakin besar PPM yang di tampilkan maka semakin lama juga waktu yang di butuhkan untuk alat (sensor) untuk kembali ke pengukuran 0 PPM.

Hasil pengujian koneksi Wifi menunjukkan, data logging tidak akan bekerja jika perangkat PC (Personal Computer) berada diluar jarak jangkauan LAN yang tersedia. Dimana dengan menggunakan penghalang jarak koneksi anatar, perangkat modul dengan perangkat PC maksimal 10-12 meter, sedangkan tanpa penghalang maksimal 16-18 meter.

Penelitian lanjutan dapat dilakukan dengan pengembangkan tampilan aplikasi sistem yang lebih menarik dan inovatif. Pengembangan sistem yang bekerja secara aktif juga bisa dilakukan, dimana sistem ini tidak menunggu gas mendekat, tetapi secara aktif memasukkan gas ke sistem melalui fan atau metode vacuum dan juga akses untuk data logging sistem pemantau gas tidak hanya dalam ruang lingkup LAN, tetapi juga dalam ruang lingkup WAN via internet.

\section{Daftar Pustaka}

Alam, M. A. J. (2003). Mengelola Database dengan Borland Delphi 7. Jakarta: Elex Media Komputindo.

Anwari, M.Z. (2011), Informasi Kadar CO dan NOX Berbasis SMS. Tersedia di http://repository.amikom.ac.id/index.php/add_dow
nloader/Naskah Publikasi\%2007.11.1700.pdf/308 $6 / 2012$

Handriyanto, D. F. (2009). Kajian Penggunaan Mikrotik Router OSTM Sebagai Router pada Jaringan Komputer. Jurnal Teknik Informatika.

Hendrayudi (2008). Pemrograman Delphi 8.0. Bandung: Yrama Widya.

Ichwan, M. (2010). Pemrograman Basis Data dan Delphi 7 dan MySQL. Bandung: Informatika.

Maryanto, D, Mulasari, S.A, Suryani, D. (2009) Penurunan Kadar Emisi Gas Buang Karbon Monoksida (CO) Dengan Penambahan Arang Aktif Pada Kendaraan Bermotor Di Yoyakarta. Kesmas, 3(3), 198-205.

Muchsin, M., Rofii, F., Jaenuri, I. (2014). Rancang Bangun Prototype Monitoring Kemanan Rumah Berbasis Closed Circuit TelEvision (Cctv) Dengan Detektor Gerak," Widya Teknika, 22(1), 7-13.

Mulyono, Misbah, Ariwinarno, H. (2015). Pembuatan Alat Deteksi Pencemaran Udara Untuk Gas Buang Industri $\left(\mathrm{H}_{2} \mathrm{~S}\right.$ dan $\left.\mathrm{NH}_{3}\right)$ Berbasis Mikrokontroller. Tersedia http://digilib.umg.ac.id/files/disk1/18/jipptumg-mulyonomis-1783-1-27-44pe-r.pdf

Rahma, R.A.A, Prasetya, T.A.E. (2016). Pengaruh Paparan $\mathrm{CH}_{4}$ Dan $\mathrm{H}_{2} \mathrm{~S}$ Terhadap Keluhan Gangguan Pernapasan Pemulung Di TPA Mrican Kabupaten Ponorogo, Universitas Darussalam Gontor, Ponorogo. Journal of Industrial Hygiene and Occupational Health, 1(1), 1-14.

Saputri, Z. N. (2014). Aplikasi Pengenalan Suara Sebagai Pengendali Peralatan Listrik Berbasis Arduino Uno. Skripsi. Malang: Universitas Brawijaya.

Sartika K, Dian (2012). Analisis Konsekuensi Dispersi Gas, Kebakaran, Dan Ledakan Akibat Kebocoran Tabung gas LPG $12 \mathrm{Kg}$ Di Kelurahan Manggarai Selatan Tahun 2012 Dengan Menggunakan Breeze Incident Analyst Software. Skripsi. Fakultas Kesehatan Masyarakat Dan Kesehatan Kerja. Universitas Indonesia.

Tiffani, B. V. (2015). Rancang Bangun Uninterruptible Power Supply Menggunakan Tampilan LCD Berbasis Mikrokontroler. Jurnal Teknik Elektro dan Komputer, 4(2), 1-7.

Vidy, M. (2014). Pengendali Saklar Listrik Melalui Ponsel Pintar Android. Jurnal Teknik Elektro dan Komputer, 3(1), 1-9.

Yusad, Y. (2003). Polusi Udara di kota-kota besar di dunia. Tersedia di http://repository.usu.ac.id/handle/123456789/3736 